\title{
The Ataxic Cacnala-Mutant Mouse Rolling Nagoya: An Overview of Neuromorphological and Electrophysiological Findings
}

\author{
Jaap J. Plomp • Arn M. J. M. van den Maagdenberg • \\ Simon Kaja
}

Published online: 30 May 2009

(C) The Author(s) 2009. This article is published with open access at Springerlink.com

\begin{abstract}
Homozygous rolling Nagoya natural mutant mice display a severe ataxic gait and frequently roll over to their side or back. The causative mutation resides in the Cacnala gene, encoding the pore-forming $\alpha_{1}$ subunit of $\mathrm{Ca}_{\mathrm{v}} 2.1$ type voltage-gated $\mathrm{Ca}^{2+}$ channels. These channels are crucially involved in neuronal $\mathrm{Ca}^{2+}$ signaling and in neurotransmitter release at many central synapses and, in the periphery, at the neuromuscular junction. We here review the behavioral, histological, biochemical, and neurophysiological studies on this mouse mutant and
\end{abstract}

J. J. Plomp $(\bowtie) \cdot$ A. M. J. M. van den Maagdenberg

Department of Neurology, Leiden University Medical Centre,

Research Building, S5P, room T-05-032, P.O. Box 9600,

2300 RC Leiden, The Netherlands

e-mail: j.j.plomp@lumc.nl

\section{J. J. Plomp}

Department of Molecular Cell Biology-Group Neurophysiology, Leiden University Medical Centre,

P.O. Box 9600, 2300 RC Leiden, The Netherlands

A. M. J. M. van den Maagdenberg

Department of Human Genetics,

Leiden University Medical Centre,

P.O. Box 9600, 2300 RC Leiden, The Netherlands

S. Kaja

Michael Smith Laboratories, The University of British Columbia, 301-2185 East Mall,

Vancouver, BC V6T 1Z4, Canada

S. Kaja

Department of Behavioral Pharmacology II, NeuroSearch A/S,

Pederstrupvej 93,

2750 Ballerup, Denmark discuss its usefulness as a model of human neurological diseases associated with $\mathrm{Ca}_{\mathrm{v}} 2.1$ dysfunction.

Keywords Ataxia - Rolling Nagoya mouse · Cacnala mutation $\cdot \mathrm{Ca}_{\mathrm{v}} 2.1 \mathrm{Ca}^{2+}$ channel . Synaptic transmission

\section{Introduction}

The ataxic mouse rolling Nagoya $(\mathrm{RN})$ is a natural mutant of which the neurological phenotype and cerebellar characteristics have been studied quite extensively in the first years following its initial report back in 1973 by Oda [1]. Research on this mouse mutant revived in 2000 when the causative mutation was identified in the Cacnala gene, encoding the pore-forming $\alpha_{1}$ subunit of $\mathrm{Ca}_{\mathrm{v}} 2.1$ (P/Q-type) voltage-gated $\mathrm{Ca}^{2+}$ channels [2]. This type of channel is involved in neuronal $\mathrm{Ca}^{2+}$ signaling and also in neurotransmitter release at many central synapses as well as the neuromuscular junction (NMJ) in the periphery [3, 4]. The discovery of the RN mutation in Cacnala was of particular interest because mutations in the orthologous human gene had in the meantime been identified in patients suffering from inherited forms of migraine and ataxia [5]. Besides, the same $\mathrm{Ca}_{\mathrm{v}} 2.1$ channels were shown to be the autoimmune targets at the NMJ in the paralytic disorder Lambert-Eaton myasthenic syndrome (LEMS) [6]. These developments, therefore, designated the RN mouse (together with other $\mathrm{Ca}_{\mathrm{v}} 2.1$ mouse mutants) as a potential model for $\mathrm{Ca}_{\mathrm{v}} 2.1$ channelopathies. In this review, we will provide an overview on the neurochemical, -physiological, and -morphological findings in the RN mouse and will discuss its usefulness in studying ataxia, migraine, and neuromuscular synapse dysfunction. 


\section{Rolling Nagoya Phenotype}

The RN mutant mouse was first described 35 years ago by Oda [1]. It was identified as a natural mutant among descendants of a cross between the SIII and C57Bl/6JNA strains but maintained on a $\mathrm{C} 3 \mathrm{Hf} / \mathrm{Nga}$ background [1]. Later studies showed that the RN mutation was allelic to the tottering mutation, which had been mapped on chromosome 8 [7]. A prominent phenotype in homozygous $\mathrm{RN}$ mice is a broad-based, severe ataxic gait with motor deficits that are characterized by frequent lurching of the mice and abnormal cyclic movements of the hind limbs when walking (Fig. 1). These symptoms of motor disturbances of the hind limbs and balancing difficulties become noticeable between postnatal days 10 and 14. RN mice do not show trunk tremor during movement or at rest. In addition, they have a $25-30 \%$ reduction in body weight $[8,9]$. The motor symptoms in $\mathrm{RN}$ males make coitus difficult, causing a reduced breeding capacity. Females are fertile but produce less surviving offspring due to poor nursing abilities [7]. Still, once successfully gone through the weaning period, $\mathrm{RN}$ mice have a normal life span [7]. Heterozygous RN mice display no overt neurological symptoms.

A more detailed characterization of ataxia in $\mathrm{RN}$ revealed abnormalities in several motor tasks [10]. For instance, compared to wild-type littermates, RN mice underperformed by frequent falling from a 2-mm-thin horizontal wire or by falling or showing persistent exhibition of headupward descent from a thick vertical rope, whereas wildtype mice from postnatal day 16 predominantly used a head-downward descent. In addition, footprint analysis revealed that $\mathrm{RN}$ mice used "double stepping of the same hind limb" in an attempt to compensate for their locomotor disability and being able to transverse forward as well as possible. In addition to the motor coordination defects and body weight reduction, RN mice exhibit muscle weakness [9]. This was shown in grip strength measurements that revealed a $62 \%$ reduction in pulling force compared to wild type. In addition, fatigability of limb muscles of RN mice was demonstrated in the inverted grid hanging test: hanging times of RN mice ranged from only 7 to $16 \mathrm{~s}$, whereas almost all wild-type mice completed the maximum recording period of $300 \mathrm{~s}$.

The severity of the phenotype in RN mice is intermediate to that of other natural $\mathrm{Ca}_{\mathrm{v}} 2.1$ mouse mutants (Table 1). The ataxia is more severe than in tottering but less severe than in leaner mice. Notably, RN mice do not show the absence or motor seizures present in the latter mutants [11], nor do they exhibit paroxysmal dyskinesis as seen in tottering mice [12]. Interestingly, compound heterozygous mice with $\mathrm{RN}$ and tottering alleles show abnormal locomotor activities and a wobbly gait of the RN mice, but not the typical epileptiform seizures seen in the tottering mice.

\section{Locus of the Rolling Nagoya Mutation}

The RN mouse mutation was only relatively recently mapped to the Cacnala gene, located on mouse chromosome 8 , encoding the pore-forming $\alpha_{1}$-subunit of neuronal $\mathrm{Ca}_{\mathrm{v}} 2.1$ (P/Q-type) $\mathrm{Ca}^{2+}$ channels [2]. The mutation is a Cto-G change at nucleotide position 3784 of the gene that results in a charge-neutralizing amino acid change from a highly conserved arginine to glycine at position 1262 in the $\mathrm{Ca}_{\mathrm{v}} 2.1-\alpha_{1}$ protein (Fig. 2). The R1262G mutation disturbs the characteristic pattern of positively charged amino acids of one of the channel's voltage sensors, localized in the fourth transmembrane segment of the third repeating domain, which reduces the voltage sensitivity of the channel (see below).

$\mathrm{Ca}_{\mathrm{v}} 2.1$ channels belong to the group of high voltageactivated $\mathrm{Ca}^{2+}$ channels that also includes $\mathrm{Ca}_{\mathrm{v}} 1$ (L-type), $\mathrm{Ca}_{\mathrm{v}} 2.2$ (N-type), and $\mathrm{Ca}_{\mathrm{v}} 2.3$ (R-type) channels. Localized in the membranes of both cell bodies and presynaptic terminals [3, 4], $\mathrm{Ca}_{\mathrm{v}} 2.1$ channels are involved in neuronal $\mathrm{Ca}^{2+}$ signaling pathways, including those involved in gene expression [13], and are key mediators of neurotransmitter release in both the central and the peripheral nervous

Fig. 1. Homozygous rolling

Nagoya mice while rolling on their back (left panel) or side (right panel). Wild-type littermate at top of left panel
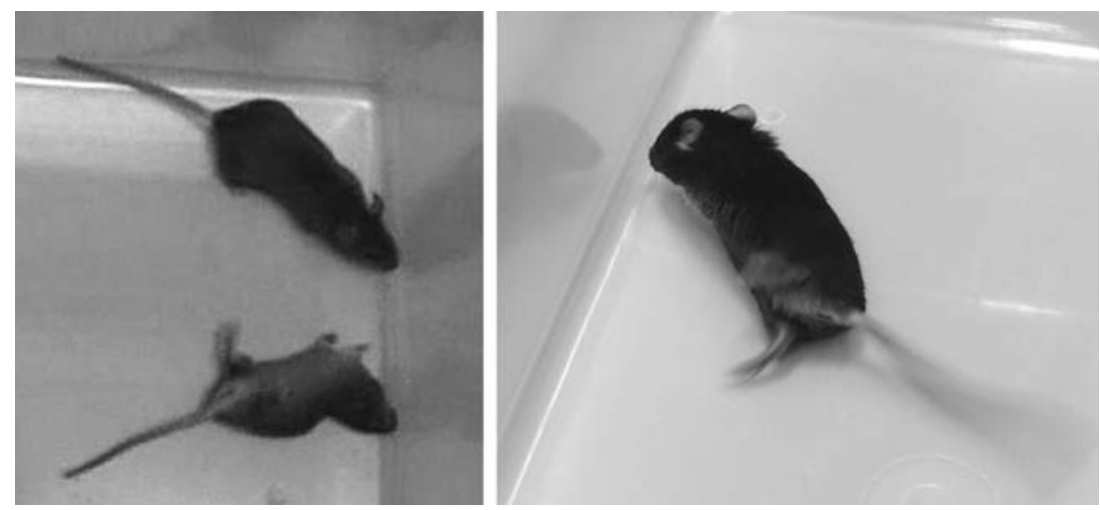
Table 1 Genetic, behavioral, neuropathological, and electrophysiological characteristics of the rolling Nagoya mouse in comparison to other natural and induced Cacnala mouse mutants

\begin{tabular}{|c|c|c|c|c|c|c|}
\hline \multirow[t]{2}{*}{ Mutant } & \multirow[t]{2}{*}{ Cacnala mutation } & \multicolumn{2}{|l|}{ Neurological phenotype } & \multirow{2}{*}{$\begin{array}{l}\text { Cerebellar } \\
\text { atrophy }\end{array}$} & \multirow{2}{*}{$\begin{array}{l}\text { Main electrophysiological } \\
\text { defects } \mathrm{Ca}_{\mathrm{v}} 2.1\end{array}$} & \multirow[t]{2}{*}{ References } \\
\hline & & Symptoms & $\begin{array}{l}\text { Dominant } \\
\text { or recessive }\end{array}$ & & & \\
\hline rolling Nagoya & Missense R1262G & Ataxia & $\mathrm{r}$ & $?$ & $\begin{array}{l}\text { Positive shift activation voltage } \\
\text { Reduced current density }\end{array}$ & {$[2]$} \\
\hline tottering & Missense P601L & $\begin{array}{l}\text { Ataxia, epilepsy, } \\
\text { dyskinesia, dystonia }\end{array}$ & $\mathrm{r}$ & - & Reduced current density (?) & {$[2,6,59-62]$} \\
\hline leaner & $\begin{array}{l}\text { Splice site mutation: } \\
\text { truncated and aberrant } \\
\text { cytoplasmatic } \\
\text { C-terminus }\end{array}$ & $\begin{array}{l}\text { Severe ataxia, epilepsy, } \\
\text { premature death }\end{array}$ & $\mathrm{r}$ & + & $\begin{array}{l}\text { Reduced current density } \\
\text { Positive shift activation voltage (?) }\end{array}$ & {$[61-63]$} \\
\hline rocker & Missense $\mathrm{T} 1310 \mathrm{~K}$ & $\begin{array}{l}\text { Ataxia, epilepsy, } \\
\text { intention tremor }\end{array}$ & $\mathrm{r}$ & - & Reduced current density & {$[64,65]$} \\
\hline wobbly & Missense R1255L & Ataxia & d & + & Not studied yet & {$[66]$} \\
\hline Cacnala $a^{\operatorname{tg}-4 J}$ & Missense V581A & Ataxia, epilepsy & $\mathrm{r}$ & - & Positive shift activation voltage & [67] \\
\hline Cacnala $^{T g-5 J}$ & Missense R1252Q & $\begin{array}{l}\text { Ataxia, premature death } \\
\text { (of homozygote) }\end{array}$ & $\mathrm{d}$ & - & Negative shift activation voltage & {$[67]$} \\
\hline R192Q knockin & Missense R192Q & None & na & - & Negative shift activation voltage & {$[54]$} \\
\hline knockout & null & Ataxia, epilepsy & $\mathrm{r}$ & + & Absent current & {$[68,69]$} \\
\hline
\end{tabular}

$d$ dominant, $r$ recessive, na not applicable, + present, - absent, ? controversial

system. Immunohistochemical and in situ hybridization studies have shown that $\mathrm{Ca}_{\mathrm{v}} 2.1$ protein and mRNA are abundantly and broadly distributed over almost all brain areas, with a particularly high expression in the cerebellum $[3,14-16]$. In the periphery, $\mathrm{Ca}_{\mathrm{v}} 2.1$ channels are present at presynaptic motor nerve terminals at the NMJ [4, 17]. In vivo, the Cacnala-encoded $\mathrm{Ca}_{\mathrm{v}} 2.1-\alpha_{1}$ subunit is associated with auxiliary subunits of the $\alpha_{2} \delta, \beta$, and $\gamma$ families, which modulate the properties of the channel. In recent years, a large number of mutations in the $\mathrm{Ca}_{\mathrm{v}} 2.1$ channel has been identified and shown to underlie several human neurological disorders, including inherited forms of migraine, episodic ataxia, and epilepsy (Table 2) [18].

\section{Morphological Studies of Rolling Nagoya Cerebellum and Other Brain Areas}

Many studies investigated RN brain anatomy and morphology as well as the expression and distribution of neurotransmitter receptors in the RN brain. Since the early studies on cerebellar anatomy, there has been a controversy on the presence or absence of cerebellar atrophy and apoptosis. While some of the older studies showed a small cerebellar volume, reduced weight and a reduction in the total number of granule, basket, and superficial stellate cells, others found a normal anatomy (for summary overview, see "Introduction" of [19]). More recent studies
Fig. 2. Transmembrane topology of the $\mathrm{Ca}_{\mathrm{v}} 2 \cdot 1-\alpha_{1}$ protein, with the location of the rolling Nagoya arginine-to-glycine mutation at position 1262 (R1262G) in the voltage-sensing S4 segment of the third repeating domain. Also indicated are the localizations of the mutations of other Cacnala mouse mutants

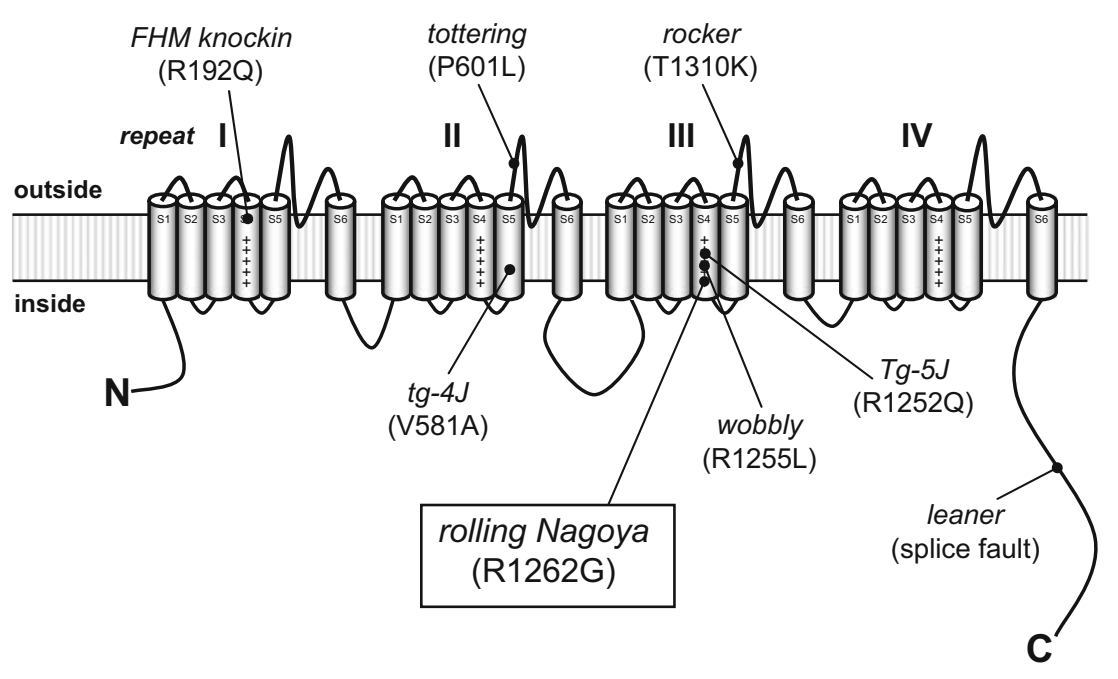


Table 2 Human $\mathrm{Ca}_{\mathrm{v}} 2.1$ channelopathies

\begin{tabular}{|c|c|c|c|}
\hline Disorder & Main symptoms & Etiology & References \\
\hline $\begin{array}{l}\text { Familial hemiplegic migraine } \\
\text { type-1 }\end{array}$ & $\begin{array}{l}\text { Migraine attacks with aura } \\
\text { Hemiparesis during migraine aura } \\
\text { Sometimes (progressive) ataxia }\end{array}$ & $\begin{array}{l}\text { Genetic: missense mutations } \\
\text { in } C A C N A 1 A\end{array}$ & {$[5,18]$} \\
\hline Episodic ataxia type-2 & $\begin{array}{l}\text { Ataxic episodes with mildly progressive baseline ataxia } \\
\text { Interictal nystagmus } \\
\text { Sometimes muscle weakness }\end{array}$ & $\begin{array}{l}\text { Genetic: truncation, deletion and } \\
\text { missense mutations in } C A C N A 1 A\end{array}$ & {$[5,18,49]$} \\
\hline Spinocerebellar ataxia type- 6 & $\begin{array}{l}\text { Late onset, slowly progressive ataxia } \\
\text { Dysarthria } \\
\text { Nystagmus }\end{array}$ & $\begin{array}{l}\text { Genetic: CAG trinucleotide } \\
\text { expansion in } C A C N A 1 A\end{array}$ & {$[48,70]$} \\
\hline Rare forms of epilepsy & $\begin{array}{l}\text { Generalized tonic-clonic epileptic seizures } \\
\text { Absence epilepsy } \\
\text { Episodic ataxia }\end{array}$ & $\begin{array}{l}\text { Genetic: missense and truncation } \\
\text { mutations in } C A C N A 1 A\end{array}$ & {$[71,72]$} \\
\hline $\begin{array}{l}\text { Lambert-Eaton myasthenic } \\
\text { syndrome }\end{array}$ & $\begin{array}{l}\text { (Proximal) muscle weakness } \\
\text { Often small-cell lung cancer } \\
\text { Sometimes autonomic dysfunction (dry mouth, impotence) } \\
\text { Sometimes ataxia }\end{array}$ & $\begin{array}{l}\text { Autoimmune: anti-Ca } 2.1 \\
\text { auto-antibodies }\end{array}$ & {$[73]$} \\
\hline
\end{tabular}

have re-addressed but not solved this question. In 3- to 4-week-old RN mice, no abnormalities in cerebellar anatomy nor apoptosis was observed [2], and deep cerebellar nuclei of 4- to 8-month-old $\mathrm{RN}$ mice had a normal cell density [20]. In contrast, others have reported (cerebellar granule cell) apoptosis in 4-month-old [21] and, especially in the anterior lobe, in 3-week-old RN mice [22]. The reasons for these discrepancies remain unclear.

In deep cerebellar nuclei, increased numbers of $\mathrm{Ca}_{\mathrm{v}} 2.1$ $\alpha_{1}$ positive neurons have been shown with immunohistochemistry, possibly as a compensatory response to reduced $\mathrm{Ca}_{\mathrm{v}} 2.1$ activity due to the RN mutation (see below) [20].

RN mice show ectopic tyrosine hydroxylase $(\mathrm{TH})$ expression in the cerebellum [2, 20,23], as also found in the other $\mathrm{Ca}_{\mathrm{v}} 2.1$ mouse mutants tottering [24] and leaner [25]. TH is normally expressed only during development and ectopic TH expression in $\mathrm{Ca}_{\mathrm{v}} 2.1$ mutants may thus be a sign of delayed neuronal maturation. Interestingly, no enzymatically active form of $\mathrm{TH}$, i.e., phosphorylated at serine residue 40, was identified in the $\mathrm{RN}$ cerebellum [26], suggesting that there is no aberrant catecholamine synthesis. Because the $\mathrm{Ca}^{2+}$ concentration in Purkinje cells is an important determinant of $\mathrm{TH}$ expression [27, 28], the ectopic TH expression in RN cerebella is likely the direct result of $\mathrm{Ca}^{2+}$ dysregulation following from $\mathrm{Ca}_{\mathrm{v}} 2.1$ dysfunction.

Increased levels of corticotropin-releasing factor (CRF) were found in some climbing fibers as well as in mossy fibers and inferior olive neurons of the RN cerebellum [20, 29, 30]. Interestingly, increased CRF immunoreactivity in climbing fibers correlated with TH-positive Purkinje cells [20]. CRF is a neuropeptide that is widely expressed throughout the central nervous system (CNS) where it acts as a neuromodulator. In Purkinje cells, CRF increases glutamate and reduces $\gamma$-aminobutyric acid (GABA) sensitivity [31]. Furthermore, it can potentiate $\mathrm{Ca}_{\mathrm{v}} 1$ (Ltype) currents [32]. It is perceivable how a similar mechanism in the $\mathrm{RN}$ cerebellum could result in $\mathrm{Ca}^{2+}$ dysregulation and cause ectopic $\mathrm{TH}$ expression. Of note, $\mathrm{Ca}_{\mathrm{v}} 1.2$ channels are selectively upregulated in the cerebellum, but not forebrain, of tottering mice [33], which also show prominent ectopic TH expression.

Expression of ryanodine receptors type 1 and 3 is altered in the RN cerebellum [34], indicating a possible disturbance of intracellular $\mathrm{Ca}^{2+}$ mobilization from the endoplasmatic reticulum. Autoradiography studies have shown reduced levels of $\mathrm{GABA}_{\mathrm{A}}$ and adenosine $\mathrm{A}_{1}$ receptors in the cerebellum and of $A_{1}$ receptors in the cerebral cortex and caudate-putamen. Furthermore, benzodiazepine binding sites were found reduced in the cerebral cortex and increased in the CA1 subfield of the hippocampus [35].

Although the motor disturbances in $\mathrm{RN}$ mice are generally typified as cerebellar ataxia, based on behavioral, histological, and physiological analyses (see below), some features also suggest extrapyramidal disturbances. Increased local cerebral glucose utilization (indicating enhanced neuronal activity) in the basal ganglia (including the globus pallidus, entopeduncular nucleus, substantia nigra reticulate, and subthalamic nucleus) as well as electrophysiological abnormalities recorded in the globus pallidus have led to the hypothesis that motor disturbances of RN mice may perhaps in the end be not so much due to cerebellar dysfunction but rather due to striatial dysfunction $[19,36]$. In addition, radiochemical studies have shown increased preproenkephalin and preprotachykinin mRNA in the striatum [37]. More research is clearly needed to shed light 
on how (combined) striatal and cerebellar dysfunction causes motor dysfunction in RN mice.

Taken together, there is much histological and biochemical evidence of altered expression levels of a multitude of intracellular and membrane proteins in many structures of the $\mathrm{RN}$ brain. These changes may, in principle, all contribute to motor dysfunction but must be secondary (developmental or compensatory) phenomena resulting from the primary defect in $\mathrm{RN}$, namely a disturbed $\mathrm{Ca}^{2+}$ signaling due to the dysfunction of $\mathrm{Ca}_{\mathrm{v}} 2.1$ channels resulting from the $\mathrm{RN}$ missense mutation.

\section{Functional Consequences of the Rolling Nagoya Mutation in $\mathrm{Ca}_{\mathrm{v}}$ 2.1 Channels}

The consequences of the RN mutation on the biophysical properties of $\mathrm{Ca}_{\mathrm{v}} 2.1$ channels have been investigated both in primary Purkinje cell cultures obtained from $\mathrm{RN}$ mice and in a heterologous expression system [2]. When expressing $\mathrm{RN}$-mutated $\mathrm{Ca}_{\mathrm{v}} 2 \cdot 1-\alpha_{1}$ in baby hamster kidney cells that also stably express the auxiliary subunits $\alpha_{2} \delta$ and $\beta_{1 \text { a }}$, whole cell peak current density (with $\mathrm{Ba}^{2+}$ as charge carrier) was reduced by nearly $75 \%$, compared with the wild-type control. Furthermore, the mutation affected the voltage dependence of activation of $\mathrm{Ca}_{\mathrm{v}} 2.1$ channels, shifting the midpoint of activation by $\sim 10 \mathrm{mV}$ in the positive direction and increasing the slope factor by $\sim 2 \mathrm{mV}$, demonstrating a shallower voltage dependence. In contrast, the voltage of inactivation of $\mathrm{RN} \mathrm{Ca} 22.1$ channels was unaffected in these experiments. $\mathrm{Ca}_{\mathrm{v}} 2.1$ type $\mathrm{Ca}^{2+}$ currents measured in native cerebellar Purkinje cell bodies were similarly affected by the RN mutation, showing reduced density $(\sim 25 \%)$, a positive shift $(\sim 8 \mathrm{mV})$ of the midpoint of the voltage of activation, and a $\sim 1 \mathrm{mV}$ increase of the slope factor. In contrast to heterologously expressed channels, the inactivation voltage midpoint was shifted by $\sim 9 \mathrm{mV}$ in the positive direction in native RN Purkinje cells. The finding of a reduced voltage sensitivity nicely demonstrates that the $\mathrm{R} 1262 \mathrm{G}$ mutation indeed affects the function of the voltage sensor of $\mathrm{Ca}_{\mathrm{v}} 2.1$ channels, resulting in diminished $\mathrm{Ca}_{\mathrm{v}} 2.1$ activity in Purkinje and other cells expressing this channel, which likely is the initial factor in the cascade that ultimately results in the ataxic RN phenotype.

\section{Neurophysiological Effects of the Rolling Nagoya Mutation}

\section{Aberrant Firing Pattern in Purkinje Neurons}

Current-clamp analyses at Purkinje cell somata in RN brain slices revealed a disturbed firing pattern of action potentials upon stimulation with large depolarizing currents [2]. The repetitive firing of $\mathrm{Na}^{+}$action potentials was aborted due to interspike depolarization, reminiscent of the effect of blocking $\mathrm{Ca}^{2+}$-activated $\mathrm{K}^{+}$channels by $\mathrm{Cd}^{2+}$ in wild-type neurons. These channels are important for post-spike repolarization and are presumably activated by the $\mathrm{Ca}^{2+}$ influx through $\mathrm{Ca}_{\mathrm{v}} 2.1$ channels on the soma and dendritic tree of the Purkinje cell. Apparently, reduced $\mathrm{Ca}_{\mathrm{v}} 2.1$ function in RN Purkinje cell dendritic tree and/or soma leads to impaired repolarization, causing impairment of high-frequency spiking. Reduced current through RNmutated $\mathrm{Ca}_{\mathrm{v}} 2.1$ channels was further indicated by the observation that $\mathrm{Ca}^{2+}$ spikes were hard to evoke in $\mathrm{RN}$ cells. Together, these experimental findings suggest that the RN mutation impairs the neuronal firing behavior of Purkinje cells (in response to synaptic integration) and thus affects cerebellar neuronal network function, contributing to the ataxia. Similar observations have been made in other $\mathrm{Ca}_{\mathrm{v}}$ 2.1-mutant mice [38]. These findings do not exclude involvement of brain areas other than the cerebellum in causing the movement abnormalities of $\mathrm{RN}$ mice. For instance, spontaneous firing rate of globus pallidus neurons in the basal ganglia is increased, likely resulting from a diminished inhibitory input [19].

Synaptic Dysfunction

\section{Cerebellum}

Cerebellar synaptic dysfunction in $\mathrm{RN}$ mice is highly likely in view of the demonstrated causative mutation in $\mathrm{Ca}_{\mathrm{v}} 2 \cdot 1-\alpha_{1}$ and the abundance of this channel at cerebellar nerve terminals [3]. Cerebellar cortical Purkinje cell dendrites receive extensive (excitatory) synaptic input from nerve terminals of climbing and parallel fibers, and there are many other synaptic connections within the cerebellum that contribute to network function [39]. There has been only very limited study of the details of cerebellar synaptic transmission in the RN mouse. Neurochemistry studies in cerebellar homogenates showed increased concentration of neurotransmitters glutamate, serotonin, noradrenaline, and dopamine and decreased glycine [8, 40]. Morphological studies showed abnormally shaped Purkinje cell dendritic spines and single parallel fiber varicosities making multiple synaptic contacts, not observed in the wild-type [21]. While these biochemical and histological studies roughly indicated neurotransmission deficits in the RN cerebellum, they did not provide detailed insight in the synaptic dysfunction. To our knowledge, there is only one study in which cerebellar synaptic function in $\mathrm{RN}$ mice was characterized with direct and detailed electrophysiological measurements. Matsushita and colleagues [41] measured with voltage-clamp methods in brain slices the glutamatergic synaptic currents originating 
from neurotransmission in parallel fiber as well as climbing fiber synapses on Purkinje cells. They found reduced excitatory postsynaptic currents at parallel fiber synapses, with increased paired-pulse facilitation. With $\mathrm{Ca}^{2+}$ channel type-selective toxins, it was shown that presynaptic $\mathrm{Ca}^{2+}$ influx at wild-type parallel fiber synapses is jointly mediated by $\mathrm{Ca}_{\mathrm{v}} 2.1,-2.2$, and presumably -2.3 type channels, where $\mathrm{Ca}_{\mathrm{v}} 2.1$ is the predominant subtype. In $\mathrm{RN}$, the $\mathrm{Ca}_{\mathrm{v}} 2.1$ contribution is somewhat reduced, while those of $\mathrm{Ca}_{\mathrm{v}} 2.2$ and -2.3 are somewhat increased. Interestingly, the situation in climbing fiber synapses is completely different. Excitatory postsynaptic currents in these synapses are enhanced and display a slower decay phase, compared to wild type. There is normal triggering of Purkinje cell spikes by climbing fiber synaptic transmission. Specific $\mathrm{Ca}_{\mathrm{v}} 2.1$ contribution to neurotransmitter release was found clearly reduced, while that of $\mathrm{Ca}_{\mathrm{v}} 2.2$ was increased. Pharmacological analyses indicated that the increased and broadened excitatory postsynaptic currents are rather due to increased postsynaptic sensitivity to glutamate than to increased presynaptic release.

\section{Neuromuscular Junction}

Besides being a predominant presynaptic $\mathrm{Ca}^{2+}$ channel in the $\mathrm{CNS}, \mathrm{Ca}_{\mathrm{v}} 2.1$ channels are also present in the peripheral nervous system at intramuscular motor nerve terminals where they mediate the release of acetylcholine (ACh) at the NMJ [4, 17, 42]. Therefore, NMJ dysfunction is to be expected in Cacnala-mutant mice. We have tested this hypothesis with detailed electrophysiological methods in several mutants [43-45], including RN [9]. We observed a large reduction (50-75\%, depending on the muscle type) of nerve stimulation-evoked ACh release at RN NMJs (Fig. 3). Interestingly, this was accompanied by a $\sim 3$-fold increase of
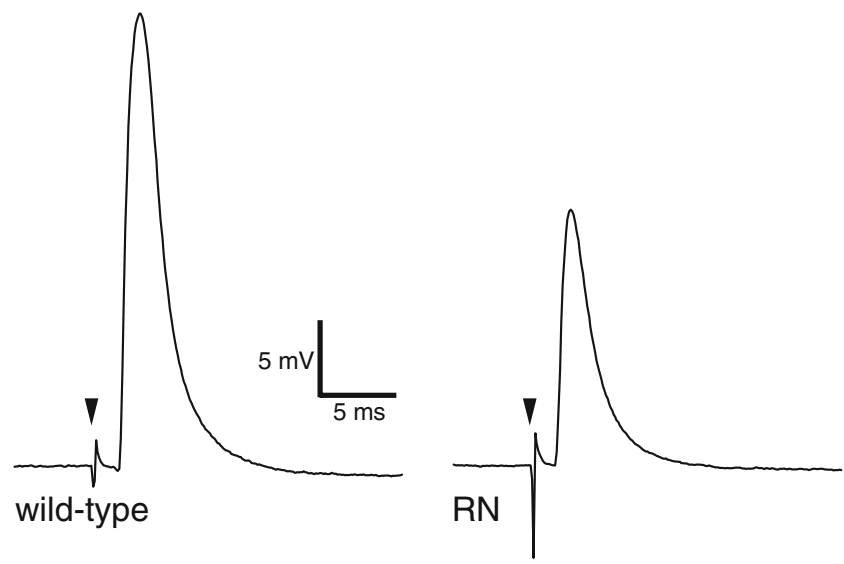

Fig. 3. Reduced amplitude of the endplate potential due to reduced acetylcholine release at the neuromuscular synapse of the rolling Nagoya mouse, recorded in an ex vivo diaphragm-phrenic nerve muscle nerve preparation with intracellular electrophysiological techniques. Black triangle indicates moment of nerve stimulation spontaneous ACh release, measured as miniature endplate potential frequency. $\mathrm{RN}$ is the only Cacnala mouse mutant so far in which opposing effects on spontaneous and evoked ACh release were found by us. Most likely, they result from a complex effect of the mutation on different functional channel parameters, allowing for increased $\mathrm{Ca}^{2+}$ influx at resting potential while limiting $\mathrm{Ca}^{2+}$ influx upon depolarization by a nerve impulse. Compensatory non- $\mathrm{Ca}_{\mathrm{v}} 2.1$ channels appear to be absent, as the selective $\mathrm{Ca}_{\mathrm{v}} 2.1$ channel blocker $\omega$-agatoxin-IVA reduced evoked ACh release by $\sim 95 \%$ in both wild-type and $\mathrm{RN}$ NMJs. Reduced $\mathrm{ACh}$ release at NMJs most likely underlies the muscle weakness and fatigue we observed in grip strength and inverted grid hanging tests of RN mice; this was further substantiated by our finding of a reduced and decrementing compound muscle action potential with in vivo electromyography and a reduced safety factor of neuromuscular synaptic transmission in ex vivo muscle contraction experiments. Therefore, our NMJ studies indicate that the gait abnormality of RN mice is likely due to a combination of ataxia and muscle weakness and that the RN mouse models, besides ataxia, aspects of the NMJ dysfunction in LEMS (see below), where presynaptic $\mathrm{Ca}_{\mathrm{v}} 2.1$ channels are targeted by auto-antibodies [6].

\section{Does the Rolling Nagoya Mouse Form a Good Model for (Aspects of) Human Neurological Disease?}

\section{Ataxia}

The ataxic phenotype of RN mice has been described in much detail [10] and is not "contaminated" by epileptic seizures, as seen in other Cacnala-mutant strains such as tottering, leaner, rocker, and null-mutants (Table 1) [46, 47]. Therefore, the RN mouse seems a valuable ataxia model, suitable for testing the anti-ataxic properties of (experimental) drugs, especially in the context of human CACNA1A mutation-related cerebellar ataxia [5, 48, 49]. Such studies are needed because current drug treatment of ataxia is not optimal [50]. Only a few compounds (such as acetazolamide in episodic ataxia type 2) have been reported to improve ataxia, but none of them has been studied in a controlled or comparative way [49]. Surprisingly, few anti-ataxic drug studies have been performed using the RN mouse mutant as ataxia model. Two studies have shown anti-ataxic effects of thyrotropin-releasing hormone and synthetic analogs (with only minor hormonal activity) in RN mice, possibly due to yet undefined neuroprotective or metabolic effects on $\mathrm{RN}$ brain areas $[8,51]$. It would be of interest to test the effect of drugs acting on $\mathrm{Ca}^{2+}$-activated $\mathrm{K}^{+}$channels, in view of the likely involvement of these channels in aberrant action potential firing of cerebellar Purkinje cells of RN [2] and other ataxic Cacnala-mutant mice [38]. 
Migraine

One may wonder whether the $\mathrm{RN}$ mouse may also be a relevant animal model to study migraine, which is a common, neurovascular brain disorder of disabling attacks of headache and associated neurological symptoms [52]. After all, mutations in the $C A C N A 1 A$ gene in humans cause familial hemiplegic migraine type 1 (FHM1) [5], a rare subtype of migraine with aura with transient hemiparesis during the aura phase. FHM is considered a model for the common forms of migraine because of similar aura and headache characteristics. Moreover, the majority of FHM patients also have normal attacks of migraine without hemiparesis. Interestingly, some $20 \%$ of FHM1 patients also suffer from cerebellar ataxia that is also the prominent neurological phenotype in $\mathrm{RN}$ mice.

However, electrophysiological studies of FHM1-mutated $\mathrm{Ca}_{\mathrm{v}}$ 2.1-transfected cells and dissociated cerebellar neurons from a recently generated Cacnala knockin mouse carrying the FHM1 mutation R192Q [18, 53, 54] indicate that the consequences of FHM1 mutations on $\mathrm{Ca}_{\mathrm{v}} 2.1$ channel function are in some important respects opposite to those of the RN mutation [2]. Whereas FHM1 mutations cause gain-of-function effects on neuronal $\mathrm{Ca}^{2+}$ influx with a shift of channel activation voltage in the negative direction and increased $\mathrm{Ca}_{\mathrm{v}} 2.1$ current density, the RN mutation causes reduced $\mathrm{Ca}_{\mathrm{v}} 2.1$ current density and a shift of activation voltage in the positive direction. In view of these differences, the RN mouse seems not useful as a model for (familial hemiplegic) migraine.

\section{Lambert-Eaton Myasthenic Syndrome}

Our own neuromuscular electrophysiological analyses and muscle strength tests of RN mice [9] have revealed that this mutant shares certain aspects with the paralytic auto-immune disease LEMS, where auto-antibodies target presynaptic $\mathrm{Ca}_{\mathrm{v}} 2.1$ channels at the NMJ. Electrophysiological analysis of synaptic signals at biopsied NMJs of LEMS patients showed severely reduced ACh release [55], as found at RN NMJs. A similar presynaptic defect was present at biopsy NMJs of three congenital myasthenic syndrome patients without anti-Ca 2.1 antibodies or identified $C A C N A 1 A$ mutation but with symptoms of ataxia [56] and, furthermore, at biopsy NMJs of two episodic ataxia type 2 patients with $C A C N A 1 A$ truncation mutations [57]. Conversely, some LEMS patients have accompanying symptoms of ataxia [58]. In addition, electromyography performed in LEMS patients resembles that in $\mathrm{RN}$ mice, in that there is a low initial compound muscle action potential which decrements during low-frequency nerve stimulation (1-10 Hz). Thus, although different causes underlie the paralytic symptoms in RN mice and LEMS patients (i.e., genetic vs. auto-immune), these similarities indicate that $\mathrm{RN}$ mice can serve as a nonimmunological model for (NMJ function) aspects of LEMS and could be useful for drug studies aiming to improve treatment of NMJ dysfunction.

\section{Conclusion}

The R1262G mutation in the $\mathrm{Ca}_{\mathrm{v}} 2.1-\alpha_{1}$ protein of the $\mathrm{RN}$ mouse causes a reduced voltage sensitivity of $\mathrm{Ca}_{\mathrm{v}} 2.1 \mathrm{Ca}^{2+}$ channels. This presumably leads to reduced $\mathrm{Ca}^{2+}$ influx in cerebellar and other neurons that express the channel, causing disturbed $\mathrm{Ca}^{2+}$ signaling leading to aberrant expression of many neuronal proteins and possibly also to the apoptosis of some neurons. Also, $\mathrm{Ca}_{\mathrm{v}} 2.1$-dependent central synaptic transmission is likely to be disturbed. Together, these complex phenomena culminate in the well-described motor coordination defects of RN mice. It is yet unclear to which extent noncerebellar regions such as the basal ganglia contribute to the motor symptoms and whether cerebellar atrophy is an important factor. Neuromuscular function analyses together with synaptic studies at the NMJ indicate that, in addition to the ataxia, the $\mathrm{RN}$ phenotype has a muscle weakness component. Although the RN mouse may not represent a very good model for common forms of migraine or not even for FHM1 (defined by CACNA1A mutations), it may be useful in the experimental study of new anti-ataxic drugs and drugs that restore disturbed NMJ function.

Acknowledgments S.K. is a European Molecular Biology Organization postdoctoral fellow and trainee of the Michael Smith Foundation for Health Research. The studies of A.M.J.M. v.d. M are supported by the Centre for Medical Systems Biology (CMSB) in the framework of the Netherlands Genomics Initiative (NGI).

Open Access This article is distributed under the terms of the Creative Commons Attribution Noncommercial License which permits any noncommercial use, distribution, and reproduction in any medium, provided the original author(s) and source are credited.

\section{References}

1. Oda S (1973) The observation of rolling mouse Nagoya (rol), a new neurological mutant, and its maintenance (author's transl). Jikken Dobutsu 22:281-288

2. Mori Y et al (2000) Reduced voltage sensitivity of activation of $\mathrm{P} /$ Q-type $\mathrm{Ca} 2+$ channels is associated with the ataxic mouse mutation rolling Nagoya (tg(rol)). J Neurosci 20:5654-5662

3. Westenbroek RE et al (1995) Immunochemical identification and subcellular distribution of the alpha 1A subunits of brain calcium channels. J Neurosci 15:6403-6418

4. Westenbroek RE, Hoskins L, Catterall WA (1998) Localization of $\mathrm{Ca} 2+$ channel subtypes on rat spinal motor neurons, interneurons, and nerve terminals. J Neurosci 18:6319-6330 
5. Ophoff RA et al (1996) Familial hemiplegic migraine and episodic ataxia type- 2 are caused by mutations in the $\mathrm{Ca} 2+$ channel gene CACNL1A4. Cell 87:543-552

6. Lennon VA et al (1995) Calcium-channel antibodies in the Lambert-Eaton syndrome and other paraneoplastic syndromes. N Engl J Med 332:1467-1474

7. Oda S (1981) A new allele of the tottering locus, rolling mouse Nagoya, on chromosome no. 8 in the mouse. Jpn J Genet 56:295-299

8. Nakamura $T$ et al (2005) Taltirelin improves motor ataxia independently of monoamine levels in rolling mouse nagoya, a model of spinocerebellar atrophy. Biol Pharm Bull 28:2244-2247

9. Kaja S et al (2007) Severely impaired neuromuscular synaptic transmission causes muscle weakness in the Cacnala-mutant mouse rolling Nagoya. Eur J Neurosci 25:2009-2020

10. Tamaki Y, Oda S, Kameyama Y (1986) Postnatal locomotion development in a neurological mutant of rolling mouse Nagoya. Dev Psychobiol 19:67-77

11. Noebels JL (1984) Isolating single genes of the inherited epilepsies. Ann Neurol 16(Suppl):S18-S21

12. Green MC, Sidman RL (1962) Tottering - a neuromusclar mutation in the mouse. And its linkage with oligosyndacylism. J Hered 53:233-237

13. Sutton KG, McRory JE, Guthrie H, Murphy TH, Snutch TP (1999) P/Q-type calcium channels mediate the activity-dependent feedback of syntaxin-1A. Nature 401:800-804

14. Mori $Y$ et al (1991) Primary structure and functional expression from complementary DNA of a brain calcium channel. Nature 350:398-402

15. Starr TV, Prystay W, Snutch TP (1991) Primary structure of a calcium channel that is highly expressed in the rat cerebellum. Proc Natl Acad Sci U S A 88:5621-5625

16. Ludwig A, Flockerzi V, Hofmann F (1997) Regional expression and cellular localization of the alphal and beta subunit of high voltage-activated calcium channels in rat brain. J Neurosci 17:1339-1349

17. Day NC et al (1997) Differential localization of voltage-dependent calcium channel alpha1 subunits at the human and rat neuromuscular junction. J Neurosci 17:6226-6235

18. Van Den Maagdenberg AM, Haan J, Terwindt GM, Ferrari MD (2007) Migraine: gene mutations and functional consequences. Curr Opin Neurol 20:299-305

19. Tomoda H, Kato M, Sakata S, Shima F (1992) Striatal dysfunction in Rolling mouse Nagoya: an electrophysiological study. J Neurol Sci 112:106-112

20. Sawada K, Sakata-Haga H, Ando M, Takeda N, Fukui Y (2001) An increased expression of $\mathrm{Ca}(2+)$ channel alpha(1A) subunit immunoreactivity in deep cerebellar neurons of rolling mouse Nagoya. Neurosci Lett 316:87-90

21. Rhyu IJ et al (1999) Morphologic investigation of rolling mouse Nagoya (tg(rol)/tg(rol)) cerebellar Purkinje cells: an ataxic mutant, revisited. Neurosci Lett 266:49-52

22. Suh YS, Oda S, Kang YH, Kim H, Rhyu IJ (2002) Apoptotic cell death of cerebellar granule cells in rolling mouse Nagoya. Neurosci Lett 325:1-4

23. Sawada K et al (1999) Abnormal expression of tyrosine hydroxylase immunoreactivity in cerebellar cortex of ataxic mutant mice. Brain Res 829:107-112

24. Hess EJ, Wilson MC (1991) Tottering and leaner mutations perturb transient developmental expression of tyrosine hydroxylase in embryologically distinct Purkinje cells. Neuron 6:123-132

25. Austin MC et al (1992) Expression of tyrosine hydroxylase in cerebellar Purkinje neurons of the mutant tottering and leaner mouse. Brain Res Mol Brain Res 15:227-240

26. Sawada K et al (2004) Abnormal expression of tyrosine hydroxylase not accompanied by phosphorylation at serine 40 in cerebellar Purkinje cells of ataxic mutant mice, rolling mouse Nagoya and dilute-lethal. Congenit Anom (Kyoto) 44:46-50

27. Fureman BE, Campbell DB, Hess EJ (1999) L-type calcium channel regulation of abnormal tyrosine hydroxylase expression in cerebella of tottering mice. Ann $\mathrm{N}$ Y Acad Sci 868:217-219

28. Brosenitsch TA, Katz DM (2001) Physiological patterns of electrical stimulation can induce neuronal gene expression by activating N-type calcium channels. J Neurosci 21:2571-2579

29. Sawada K et al (2003) Over-expression of corticotropin-releasing factor mRNA in inferior olivary neurons of rolling mouse Nagoya. Brain Res Mol Brain Res 117:190-195

30. Ando $M$ et al (2005) Regional difference in corticotropinreleasing factor immunoreactivity in mossy fiber terminals innervating calretinin-immunoreactive unipolar brush cells in vestibulocerebellum of rolling mouse Nagoya. Brain Res 1063:96-101

31. Bishop GA, Seelandt CM, King JS (2000) Cellular localization of corticotropin releasing factor receptors in the adult mouse cerebellum. Neuroscience 101:1083-1092

32. Kanno T, Suga S, Nakano K, Kamimura N, Wakui M (1999) Corticotropin-releasing factor modulation of $\mathrm{Ca} 2+$ influx in rat pancreatic beta-cells. Diabetes 48:1741-1746

33. Campbell DB, Hess EJ (1999) L-type calcium channels contribute to the tottering mouse dystonic episodes. Mol Pharmacol 55:23-31

34. Sawada K et al (2008) Differential alterations in expressions of ryanodine receptor subtypes in cerebellar cortical neurons of an ataxic mutant, rolling mouse Nagoya. Neuroscience 152:609-617

35. Onodera H, Takase S, Oda S, Sobue I, Kogure K (1988) Neurotransmitter receptors of the rolling mouse Nagoya: a quantitative autoradiographic study. Neurosci Res 5:316-324

36. Kato M, Hosokawa S, Tobimatsu S, Kuroiwa Y (1982) Increased local cerebral glucose utilization in the basal ganglia of the rolling mouse Nagoya. J Cereb Blood Flow Metab 2:385-393

37. Taniwaki T, Shinoda H, Kaseda Y, Kato M, Goto I (1996) Increased preproenkephalin mRNA and preprotachykinin mRNA in the striatum of Rolling mouse Nagoya. Brain Res 714:231-234

38. Walter JT, Alvina K, Womack MD, Chevez C, Khodakhah K (2006) Decreases in the precision of Purkinje cell pacemaking cause cerebellar dysfunction and ataxia. Nat Neurosci 9:389-397

39. Watanabe M (2008) Molecular mechanisms governing competitive synaptic wiring in cerebellar Purkinje cells. Tohoku J Exp Med 214:175-190

40. Muramoto O, Kanazawa I, Ando K (1981) Neurotransmitter abnormality in Rolling mouse Nagoya, an ataxic mutant mouse. Brain Res 215:295-304

41. Matsushita K et al (2002) Bidirectional alterations in cerebellar synaptic transmission of tottering and rolling $\mathrm{Ca} 2+$ channel mutant mice. J Neurosci 22:4388-4398

42. Uchitel OD et al (1992) P-type voltage-dependent calcium channel mediates presynaptic calcium influx and transmitter release in mammalian synapses. Proc Natl Acad Sci U S A 89:3330-3333

43. Plomp JJ et al (2000) Abnormal transmitter release at neuromuscular junctions of mice carrying the tottering alpha(1A) $\mathrm{Ca}(2+)$ channel mutation. Brain 123:463-471

44. Kaja $S$ et al (2005) Gene dosage-dependent transmitter release changes at neuromuscular synapses of CACNA1A R192Q knockin mice are non-progressive and do not lead to morphological changes or muscle weakness. Neuroscience 135:81-95

45. Kaja S et al (2007) Characterization of acetylcholine release and the compensatory contribution of non-Ca(v)2.1 channels at motor nerve terminals of leaner $\mathrm{Ca}(\mathrm{v}) 2.1$-mutant mice. Neuroscience 144:1278-1287

46. Pietrobon D (2002) Calcium channels and channelopathies of the central nervous system. Mol Neurobiol 25:31-50 
47. Felix R (2002) Insights from mouse models of absence epilepsy into $\mathrm{Ca}^{2+}$ channel physiology and disease etiology. Cell Mol Neurobiol 22:103-120

48. Soong BW, Paulson HL (2007) Spinocerebellar ataxias: an update. Curr Opin Neurol 20:438-446

49. Jen JC et al (2007) Primary episodic ataxias: diagnosis, pathogenesis and treatment. Brain 130:2484-2493

50. Ogawa M (2004) Pharmacological treatments of cerebellar ataxia. Cerebellum 3:107-111

51. Kinoshita K, Watanabe Y, Asai H, Yamamura M, Matsuoka Y (1995) Anti-ataxic effects of TRH and its analogue, TA-0910, in Rolling mouse Nagoya by metabolic normalization of the ventral tegmental area. Br J Pharmacol 116:3274-3278

52. International Headache society (2004) The international classification of headache disorders: 2nd edition. Cephalalgia 24(Suppl 1): $9-160$

53. Pietrobon D (2005) Function and dysfunction of synaptic calcium channels: insights from mouse models. Curr Opin Neurobiol $15: 257-265$

54. Van Den Maagdenberg AM et al (2004) A Cacnala knockin migraine mouse model with increased susceptibility to cortical spreading depression. Neuron 41:701-710

55. Lambert EH, Elmqvist D (1971) Quantal components of end-plate potentials in the myasthenic syndrome. Ann N Y Acad Sci 183:183-199

56. Maselli RA et al (2001) Presynaptic congenital myasthenic syndrome due to quantal release deficiency. Neurology 57:279-289

57. Maselli RA et al (2003) Presynaptic failure of neuromuscular transmission and synaptic remodeling in EA2. Neurology 61:1743-1748

58. Mason WP et al (1997) Small-cell lung cancer, paraneoplastic cerebellar degeneration and the Lambert-Eaton myasthenic syndrome. Brain 120:1279-1300

59. Fletcher CF et al (1996) Absence epilepsy in tottering mutant mice is associated with calcium channel defects. Cell 87:607-617

60. Doyle J, Ren X, Lennon G, Stubbs L (1997) Mutations in the Cacnl1a4 calcium channel gene are associated with seizures, cerebellar degeneration, and ataxia in tottering and leaner mutant mice. Mamm Genome 8:113-120
61. Wakamori M et al (1998) Single tottering mutations responsible for the neuropathic phenotype of the P-type calcium channel. J Biol Chem 273:34857-34867

62. Dove LS, Abbott LC, Griffith WH (1998) Whole-cell and singlechannel analysis of P-type calcium currents in cerebellar Purkinje cells of leaner mutant mice. J Neurosci 18:7687-7699

63. Lorenzon NM, Lutz CM, Frankel WN, Beam KG (1998) Altered calcium channel currents in Purkinje cells of the neurological mutant mouse leaner. J Neurosci 18:4482-4489

64. Zwingman TA, Neumann PE, Noebels JL, Herrup K (2001) Rocker is a new variant of the voltage-dependent calcium channel gene Cacna1a. J Neurosci 21:1169-1178

65. Kodama $\mathrm{T}$ et al (2006) A CaV2.1 calcium channel mutation rocker reduces the number of postsynaptic AMPA receptors in parallel fiber-Purkinje cell synapses. Eur J Neurosci 24:29933007

66. Xie $G$ et al (2007) Forward genetic screen of mouse reveals dominant missense mutation in the $\mathrm{P} / \mathrm{Q}$-type voltage-dependent calcium channel, CACNA1A. Genes Brain Behav 6:717-727

67. Miki T et al (2008) Two novel alleles of tottering with distinct $\mathrm{Ca}(\mathrm{v})$ 2.1 calcium channel neuropathologies. Neuroscience 155:31-44

68. Jun $\mathrm{K}$ et al (1999) Ablation of $\mathrm{P} / \mathrm{Q}-$ type $\mathrm{Ca}(2+)$ channel currents, altered synaptic transmission, and progressive ataxia in mice lacking the alpha(1A)-subunit. Proc Natl Acad Sci U S A 96:15245-15250

69. Fletcher CF et al (2001) Dystonia and cerebellar atrophy in Cacnala null mice lacking P/Q calcium channel activity. FASEB J $15: 1288-1290$

70. Zhuchenko O et al (1997) Autosomal dominant cerebellar ataxia (SCA6) associated with small polyglutamine expansions in the alpha 1A-voltage-dependent calcium channel. Nat Genet 15:62-69

71. Jouvenceau A et al (2001) Human epilepsy associated with dysfunction of the brain P/Q-type calcium channel. Lancet 358:801-807

72. Imbrici P et al (2004) Dysfunction of the brain calcium channel CaV2.1 in absence epilepsy and episodic ataxia. Brain 127:26822692

73. Sanders DB (2003) Lambert-Eaton myasthenic syndrome: diagnosis and treatment. Ann N Y Acad Sci 998:500-508 